\section{A attirtor}

\section{OF THE PRACTICE OF}

\section{MEDICINE AND SURGERY IN THE}

\author{
HOSPITALS OF LONDON.
} Nulla est alia pro certo noscendi via, nisi quam plurimas et morborum et
dissectionum historias, tam aliorum proprias, collectas habere et inter se comparare,-Mongagnt. De Sed. et Caus. Morb., lib. 14. Proœmium.

\section{GUY'S HOSPITAL.}

RECURRENCE OF AN ADENOCELE OR MAMMARY GLANDULAR TUMOUR AFTER THREE SUCCESSIVE REMOVALS ; ULTIMATE CURE.

(Under the care of Mr. BIRKETT:)

A THOROUGI acquaintance with the various tumours involving the mammary gland is essential to the forming of a correct opinion as to their malignancy and liability to recurrence. When growths appear at an early age-say in women under thirty-the probabilities are in favour of their benignancy, and that they pertain to the class of chronic mammary, mammary glandular, sero-cystic, or adenoid tumours, as they have been described by Sir Astley Cooper, Sir Benjamin Brodie, Mr. Birkett, and other writers. A tumour met with in the breast of a young girl, for instance, is most commonly of this nature, although occasionally there are exceptions; and when once removed, they never return. Such examples are by no means rare; many have appeared in our "Mirror." We examined two on the 17th inst. at another hospital: one in a girl of fourteen, with a small adenocele of the right breast; another in a young woman aged twenty-seven. These patients had applied for advice under the impression that their tumours were cancerous; their true nature was, however, readily made out. In the latter part of 1859 , we saw three examples in young patients, under Mr. Birkett's care at Guy's Hospital, all successfully operated upon. One of these was especially interesting, because both breasts contained a tumour; that in the lower part of the right had been growing for three or four years, and was always painful before the appearance of the catamenia; and some three or four monthe previous to her admission into the hospital, several small growths were deve loped in the left breast. The one occupying the right gland was alone removed on the present occasion. A similar form of tumour, developed during pregnancy, in a young married woman, we saw Mr. Birkett excise in October last; it had prevented suckling, and was deeply seated behind the nipple. A good recovery ensued, without damage to the proper glandular structure.

That these simple or innocuons tumours, nevertheless, do occasionally recur, we have clear evidence to prove, and the following instance is an example. There is a point of some importance in the case, moreover, not to be overlooked-viz., that although the primary disease resembled the chronic mammary tumour, yet the age of the patient was greater than that at which the malady usually shows itself; and after three removals it recurred a fourth time, the extirpation of the entire gland having been followed by perfect success thus fax. Curiously enough also, although the glandular elements were observable on each occasion, yet the tumours varied in their characters, being at one time mammary-glandular, and at another cysto-sarcomatous. In a former "Mirror," (THE LANCET, vol. ii., 1557, p. 114, we have recorded an instance in which all the varieties of tumour belonging to the class Adenocele were developed in a single breast. Its removal, however, was followed by recurrence (idem, p. 549) within four months, in consequence of the nipple having been left behind.

The case of this patient, now fifty-three years old, is reported in Mr. Birkett's paper, on Adenocele, in 'Guy's Hospital Reports" for 1855 , p. 161

The facts are as follows:-The patient was forty-five years old when the first growth was discovered. This growth had existed eleven months when removed. One year and ten months elapsed before the discovery of the second tumour, which was excised three months subsequently. In the course of eight months a third growth made its appearance, and was removed four months afterwards. All the growths showed the elements and tissues of the mammary gland structure; but the first and last most closely resembled the "chronic mammary tumour" of Sir Astley Cooper, whilst the second belonged to the class "cysto-sarcoma" of other pathologists.

This case and another are related to prove the alternation which may occur between these new growths in the same individual at different times, as well as the probable identity in their physiological relations.

In November, 1856, the patient showed Mr. Birkett a fourth very small growth near the cicatrix, but on the axillary part of the breast, which had not been taken away. She had then been free from recurrence one year and eight months. During $1857-8$, and the early part of 1859 , scarcely any increase in the tumour took place; but in the spring and during the summer it rapidly enlarged, and at the time of removal measured about four inches in the largest diameter.

This fourth growth was excised Angust 23rd, 1859, together with every particle of the normal breast gland-tissue which could be fornd. It consisted of the same elements as those composing the former growths; but in this instance it showed, with the happiest effect, a combination within the same envelope of the "chronic mammary tumour" of Sir A. Cooper, and the "cysto-sarcoma:" for in some parts were firm, fibrous, solid gland-like masses; whilst in others, cysta, with the cha racteristic fluid and intra-cystic growths, met the eye. The patient suffered very little during the healing of the wound, which was nearly complete in about a fortnight, and the patient left the hospital quite well.

\section{LONDON HOSPITAL}

\section{MAMMARY GLANDULAR AND SERO-CYSTIC TUMOUR;} AMPUTATION OF THE BREAST.

(Under the care of Mr. JoHn AdAMs.)

WHEN non-malignant growths occur in the breasts of middleaged persons, there is sometimes reason to fear that they may be actually malignant; and an examination after removal can alone determine their real nature. They would seem to hold an intermediate position, in some instances, between the can. cer of the elderly, and the mammary glandular tumour of young females. In the history of the following case, it will be noticed that there is evidence of cancer having existed in the family. There were, however, not any external manifestations of cancer, but cysts could readily be made out. After removal, it was found to be the sero-cystic disease of the breast as described by Sir Benjamin Brodie, made up of modified mammary glandular structure.

We recollect seeing $\mathrm{Mr}$. Curling remove a somewhat similar tumour from the breast of a female, whose case is recorded in our "Mirror" of the 16th September, 1858 (p. 308).

A female, aged forty eight years, of a sanguineo-lymphatic temperament, was admitted in the beginning of the present year. The left mammary region was occupied by a large, slightly pendulous tumour, which had been in course of development for five years. It was larger than three fists in volume, irregularly convex in outline, and of unequal density, and here and there a cyst could be made out superficially in its substance. Several large veins ramified over its cutaneous surface, but the skin was healthy, though attenuated, and could be moved freely over the subjacent parts; the tnmour could also be readily moved from the deeper-seated structures. The nipule was healthy, and the axillary glands were unaffected. The patient ascribed the occurrence of the swelling to a slight local injury. The pain during its growth had been very variable in duration, recurrence, and intensity, but had never been very severe; and the catamenia for the same period had been quite regular up to the time of her admission into the hospital. No hereditary tendency to mammary disease conld be traced, but the patient stated that her maternal aunt had died from a cancer.

Mr. Adams amputated the tumour after she had remained quiet for a few days in the hospital. It weighed thirty-two ounces, and was found to have been developed behind the outer two-thirds of the mammary gland, which had been removed with the tumour during the operation, the inner third being allowed to remain in situ. The diseased structure was quite distinct from the gland, condensed comnective tissue 